\title{
Cutting and Pasting: What L.M. Montgomery's Island Scrapbooks Reveal about Her Reading
}

DOI

https://doi.org/10.32393/jlmms/2021.0008

Published on

Mon, 04/05/2021 - 06:49

The text below is an introduction to and synopsis of "Cutting and Pasting: What L.M. Montgomery's Island Scrapbooks Reveal about Her Reading," a paper (available below in video form) first presented to the L.M. Montgomery international conference L.M. Montgomery and Reading in June 2018 and recorded on 31 July 2018 at the University of Prince Edward Island.

\section{An Introduction to Cutting and Pasting}

As most of us know, L.M. Montgomery was a record-keeper of the first order-in her volumes of journals and hundreds of letters, as well as in a number of scrapbooks, twelve of which contain the bulk of her published stories and poems. She also kept scrapbooks of her own book reviews and mementoes of her children's early years, and several more containing her own mementoes or souvenirs. All of these scrapbooks are kept either in the University of Guelph Library Archival and Special Collections or at the Confederation Centre of the Arts in Charlottetown.

Montgomery kept two scrapbooks of souvenirs during her Cavendish years (c. 1893-1911), the years in which she was beginning to publish many poems and stories and, eventually, her first novels, including Anne of Green Gables (1908). These scrapbooks, known as Montgomery's Island Scrapbooks, are identified by the colours of their covers: the Blue Scrapbook and the Red Scrapbook. They are among 
many Montgomery items now kept in the Confederation Centre of the Arts. Montgomery began putting items into the Blue Scrapbook in 1893 when she was about nineteen years old; most items in this scrapbook are from the 1890s, the years she was finishing her schooling in Cavendish; attending Prince of Wales College in Charlottetown and Dalhousie College in Halifax, Nova Scotia; and teaching in three Prince Edward Island schools. The Red one she began in about 1901; in November of that year she went back to Nova Scotia to work at the Daily Echo, a Halifax newspaper, and stayed until early June 1902. But for most of the years represented in the Red Scrapbook, Montgomery was living in Cavendish, caring for her elderly grandmother. In 1911 Montgomery was married to Ewan Macdonald, left Prince Edward Island, and began a new life (and new scrapbooks) in Ontario. A few items in the Red Scrapbook date well before 1901 but most are from the years 1901 to 1911. Elizabeth Epperly's book, Imagining Anne: L.M. Montgomery's Island Scrapbooks (Penguin Canada, 2008, and Nimbus, 2019; please note that all underlined text is hyperlinked to relevant resources), shows most of the pages in these two scrapbooks and includes many explanations of and insights into the hundreds of personal items on the pages, especially items that Montgomery kept from various events in her life-souvenirs such as programs and articles from her Prince of Wales College days, relics from schools and lampposts, pressed flowers from her outings with friends, fragments of fur from her pet cats, write-ups of weddings and obituaries of family members and friends, her own cyanotypes with scenes of home, and more.

There are also many items clipped from magazines, newspapers, and other sources-poems and pictures that must have meant something to her, or that, perhaps, she thought would be useful reminders and inspirations for her writing. It seems that she stored some of the clippings, or even entire publications, until she could find time or had the inclination to paste them into scrapbooks-the clippings are not arranged in strict chronological order; in fact, some pages contain clippings from different years. Neither the organization nor arrangement is immediately apparent; Montgomery may have chosen to arrange some items to fit the spaces available on the pages.

Montgomery recalls the Island scrapbooks in two long journal entries written on 30 July 1905 and 22 November 1926 and describes some of the pages and the items contained on those pages. She admits that, in some cases, she does not recall some of the items' significance. 1 In her journal entry of 16 August 1907, she discusses the 
acceptance of her first book, Anne of Green Gables, by the L.C. Page Company, recalling that she began writing it in May 1905.2 In the 30 July 1905 entry in her journal she writes about "looking over an old scrapbook" and describes many pages from the Blue Scrapbook. $\underline{3}$ From studying the scrapbooks, it seems very clear that Montgomery must have leafed through them while writing Anne and that some of the scrapbook items gave her ideas for some incidents and details readers most associate with "Anne." In Imagining Anne, Epperly identified most of the personal souvenirs, such as notes from friends, items commemorating parties or outings, and even bits of fur Montgomery clipped from her cats and placed on cards with the cats' names. However, sources of illustrations and articles from newspapers, magazines, and catalogues that Montgomery pasted on many pages had not yet been found when Epperly first published Imagining Anne in 2008. Some of these items will be identified throughout this introduction, and more details are identified in this video presentation, including illustrations mentioned in this introduction to the scrapbook sources.

When Epperly's book about the scrapbooks, Imagining Anne, was first published in 2008, $\underline{4}$ my fellow L.M. Montgomery Literary Society member Christy Woster began to search for and find some of these clippings' original sources. She wrote about her discoveries for the 2008 issue of The Shining Scroll, the L.M. Montgomery Literary Society newsletter, which can be found online. $\underline{5}$ After Woster died in 2016, her family asked me to catalogue some of her vast Montgomery collection, and, while doing so, I decided to continue her search for more sources of scrapbook items. What Woster and I discovered revealed much about the kinds of periodicals Montgomery was reading during those years in Cavendish (c. 1893 to 1911), and how they might have influenced her.

In the video that accompanies this paper (see above), sources of many (but not all) of the clippings Woster and I found and collected are shown; Woster's family and I have donated original copies of many of these sources, known as the Woster-Collins Collection, to the L.M. Montgomery Institute at the University of Prince Edward Island, so they can be seen and studied in context. The search for more sources continues. In addition, a table of contents for the two Island scrapbooks is available 
at the L.M. Montgomery Institute in the Robertson Library at the University of Prince Edward Island.

Giving a vivid and colourful look to the scrapbook pages are cut-outs of flowers, fruits, and leaves, arranged artfully around souvenirs and clippings on many of the pages. Most of these coloured cut-outs were from John Lewis Childs seed catalogues. The Childs catalogues contain many original coloured illustrations of Childs's impressive selection of plants; the catalogues are now extremely rare. (They were printed on thin newsprint and probably ended up as kindling in Waterloo stoves or in outhouses.) However, some are in archival collections and can be seen online. 6

John Lewis Childs was the first plant specialist to produce seed catalogues, beginning in 1875. He owned 1,000 acres of land in Long Island, NY, that were mostly devoted to growing and cultivating a wide range of flowers, fruits, vegetables, and exotic plants. Montgomery may have been a subscriber to the Childs catalogues-at least eleven (from 1894 to 1904)-are represented throughout the two Island scrapbooks, especially the Blue one. Keen observers of the details in Anne of Green Gables may recall the scene from Chapter 17, when Anne is "welcomed back to school with open arms." 7 Among the gifts Anne received from some of the girls in her class was this one: "Ella May MacPherson gave her an enormous yellow pansy cut from the covers of a floral catalogue-a species of desk decoration much prized in Avonlea school." 8 Could that have been inspired by the cut-out of the yellow pansy pasted in the top corner of page eighteen of the Red Scrapbook? 9

Montgomery clipped pictures from advertisements in magazines, including many from ads for soaps, oats, pianos, wire fencing, root beer, and even an ad for Crescent bicycles. (See page three of the Blue Scrapbook, 10 on which is a painting featuring a young woman sitting on a crescent moon, a favourite Montgomery motif.) "The Grocer's Smile," an ad for Quaker Oats, 11 may have influenced Marilla's comment about the "premier" in Chapter 18 of Anne of Green Gables. ("Such a nose as that man had!" was Marilla's comment.12) An ad for B.T. Babbitt's Best Soap13 shows a young girl holding a sheaf of madonna lilies and looking rather saintly. Montgomery mentioned madonna lilies in Anne of Green Gables.14 There are pictures of young ladies in beautiful gowns, a good many with puffed sleeves, which must have provided inspiration for Anne Shirley's heart's desire. 
Montgomery also clipped poems, stories, and articles that may have inspired her when she was looking for subjects to write about. One poem, "Forget Not the Old Folks at Home" by Louise S. Upham, was partly quoted in Montgomery's story "Miss Carston's Encore," found in 2019 by Benjamin Lefebvre.15 This was one of the undocumented Montgomery stories in the 1986 Wilmshurst bibliography 16 that was listed as "Miss C's Encore" in Montgomery's "ledger list." This is the only known publication of the story to date. It is not clear where Montgomery's clipping of the poem came from, but it was probably from a local (that is, a Prince Edward Island) paper. No further information on this poem has been found; thus, the copy of the poem in Montgomery's scrapbook may well be the only known copy of it.17

A small drawing of Marie Duplessis, who was considered "one of the most beautiful women in Paris," 18 was pasted on page nineteen of the Blue Scrapbook.19 Mme. Duplessis died young of consumption and was the inspiration for Alexandre Dumas's character in his novel and then stage play La Dame aux Camélias, also known as Camille. Montgomery may have clipped this portrait from The Ladies' Home Journal as a reminder of her mother who had suffered the same fate in 1876 . Several Montgomery characters also died of consumption, including Ruby Gillis in Anne of the Island 20 and Hester Gray in Anne of Avonlea.21 As Epperly points out in Imagining Anne, "the poignancy of Duplessis's story would have thrilled Anne Shirley." $\underline{22}$

There are many pictures of cats throughout the scrapbooks, most of them from paintings by Henriette Ronner, who was famous for her many feline paintings. Montgomery snipped bits of fur from her own pet cats and sewed them onto cards, which she pasted into her scrapbooks.

As far as we can determine so far, the oldest known clipping in the two scrapbooks-and undoubtedly the best known-is a clipping of the poem that inspired Montgomery from the beginning of her writing career and throughout her life: “The Fringed Gentian." 23 Its final verse especially inspired her:

Then whisper, blossom, in thy sleep,

How may I upward climb

The Alpine path so hard, so steep

That leads to heights sublime? 
How may I reach the far-off goal

Of true and honored fame,

To write upon its shining scroll

A woman's humble name? $\underline{24}$

Montgomery entitled her 1917 memoir "The Alpine Path." 25 The poem is from a serial story in Godey's Lady's Book from March 1884. (Montgomery was only nine years old at the time of its publication.) The serial, "Tam! The Story of a Woman," ran from January 1884 to June 1885. The authors of the story were Ella Rodman Church and Augusta de Bubna, both authors and poets, and were likely also the authors of this poem. The source of the poem was found by L.M. Montgomery Literary Society member Carole Gaboury who reported it in the Kindred Spirits of Vermont newsletter in 1989.26

Another clipping, the poem "Little Brown Hands" by Mary H. Krout, tells of children not only gathering wildflowers and seashells but also tossing the hay and driving the cows home. Given its sentiment that the humblest of people can become great, the last verse in the poem may have been as significant to Montgomery as that of "The Fringed Gentian," since it provides encouragement to those who come from somewhat humble backgrounds, as Montgomery did:

Those who toil bravely are strongest;

The humble and poor become great;

And from those brown-handed children

Shall grow mighty rulers of State.

The pen of the author and statesman,

The noble and wise of the land,

The sword and chisel and palette,

Shall be held in the little brown hand.27 
This poem was first published in Child Life, a collection of poems edited by John Greenleaf Whittier, in 1871.28 It was reprinted widely and Montgomery's clipping on page thirty-nine of the Red Scrapbook 29 probably came from a local newspaper.

While looking through hundreds of periodicals searching for scrapbook item sources, I became aware of many similarities in the stories and poems of L.M. Montgomery and those in the periodicals. Many stories featured characters down on their luck or orphaned, striving to better themselves, and many featured mistaken identities that resulted in happy endings. These were themes Montgomery used frequently, for instance, in "The Brother Who Failed" 30 and "A Case of Mistaken Identity." 31 Poems with nature themes and poems about rural life were very prominent themes in the scrapbook items, and Montgomery turned to these often in her own writing, for instance, in "Winter Dusk in the Firs" $\underline{32}$ and "A Country Boy." $\underline{33}$

Occasionally, I ran across items that were more than similar-they seemed to have inspired specific scenes in Montgomery's work, especially Anne of Green Gables. For instance, an illustration from a piece in The Youth's Companion caught my eye immediately. It shows a girl jumping up from her schoolroom desk with her slate in both hands, about to hit a boy over the head with it.34 Even though it was published about ten years before Montgomery said she began her work on Anne, the coincidence between it and the scene in Chapter 15 of Anne of Green Gables is striking. 35 (No pun intended.) Montgomery was a reader of The Youth's Companion -she clipped several items to put in her Blue Scrapbook from 1894 issues; for instance, the poem "The Little Brown Dog," 36 the poem "August," 37 and an ad for Wrisley's Cucumber Soap also from the 2 August issue38-and she likely would have noticed the story and illustration and perhaps even clipped it for future reference.

Another Youth's Companion piece from March 1900, published much closer to the time Montgomery began work on Anne, is a story entitled "The Disposal of Sarah Bell." 39 There are so many similarities to the first few chapters of Anne of Green Gables that it is hard to ignore them: Sarah is an orphaned eleven-year-old, dressed in a plain calico dress and wearing a straw sailor hat; she is eager to help with household chores; a "Marilla"-type character decides to keep her instead of letting her go to a "Mrs. Blewett"-type character. The March issue may even have inspired Montgomery's setting Anne's birthday in March!

We know from reading Montgomery's letters and journals that she read books on many subjects, but the scrapbooks show that she also read many periodicals over 
the years-seed catalogues; magazines for young people (such as The Youth's Companion); fashion magazines (such as The Delineator); literary magazines (such as Munsey's); international newspapers (such as The Illustrated London News); women's magazines (such as Godey's Lady's Book and The Ladies' Home Journal); and even humorous magazines with cartoons and jokes (such as Punch, Judge's Library, and Puck). From the 1880s to at least 1910, the newspapers and magazines, cards, calendars, and advertising materials Montgomery had access to, and kept, reflect a wide range of reading materials, much of which influenced her day-to-day life as well as her career. She would even publish poems and stories in some of the periodicals represented in these two Island scrapbooks: Youth's Companion, Ladies' Home Journal, Ladies' World, Delineator, Munsey's, The National, and Boys' World, all of which accompanied her on her "upward climb" along that "path, so hard, so steep" that led to "heights sublime."

About the Author: Carolyn Strom Collins is the author (with Christina Wyss Eriksson) of The Anne of Green Gables Treasury (Penguin Canada, 1991), The Anne of Green Gables Christmas Treasury (Penguin Canada, 1997), The Anne of Green Gables Treasury of Days (Penguin Canada, 1994), and companion books to Little Women, The Secret Garden, and the Little House books. In addition, she edited Anne of Green Gables: The Original Manuscript (Nimbus, 2019); After Many Years: TwentyOne "Long-Lost" Stories by L.M. Montgomery (Nimbus, 2017); and An Annotated Bibliography of L.M. Montgomery's Stories and Poems (UPEI, 2016). Presentations to the L.M. Montgomery Institute biennial international conference include explorations of Montgomery's scrapbooks, poetry, and wartime publications; the Montgomery family's arrival in Prince Edward Island; the Anne of Green Gables 1919 silent movie; and other topics. Collins scripted and narrated "A Virtual Tour of L.M. Montgomery's Prince Edward Island," which includes photography by Bernadeta Milewski, for the 2020 LMMI conference (reimagined as the 2020 Vision Forum). Recently, she contributed to "Conversations about L.M. Montgomery," arranged by Ben Lefebvre and Andrea McKenzie, with the talk "An Archive of Her Own-L.M. Montgomery's Scrapbooks and Other Records," which includes complementary information to that found in this article. Collins founded the Friends of the L.M. Montgomery Institute as well as the L.M. Montgomery Literary Society and co-edits its annual online newsletter, The Shining Scroll. She was the recipient of the L.M. Montgomery Institute's 2020 Legacy Award for her contributions to the world of L.M. Montgomery. 
Acknowledgements: Thank you to Dr. Elizabeth Epperly and Kate Macdonald Butler for their support of this project's publication in the Journal of L.M. Montgomery Studies; to Kate Scarth, Journal of L.M. Montgomery Studies editor, for her help in readying this introduction and video for the Journal; to Donald Moses and Kristy McKinney at the University of Prince Edward Island for their technical expertise with the video production; to Jane Ledwell, Abbey McRoberts, Sarah Freeburn, and Alyssa Gillespie for editorial assistance; and to Simon Lloyd for storing and displaying items from the Woster-Collins Collection at the Robertson Library at UPEI.

Banner image derived from L.M. Montgomery's Blue Scrapbook, Elizabeth Epperly's Imagining Anne: L.M. Montgomery's Island Scrapbooks (Penguin Canada, 2008, and Nimbus, 2019, pp 67-68). Photo by Carolyn Strom Collins.

- 1 Montgomery, SJ 3 (22 Nov. 1926): 313.

- 2 Montgomery, SJ 1 (16 Aug. 1907): 330.

- 3 Montgomery, SJ 1 (30 July 1905): 308.

- 4 Epperly's Imagining Anne was republished by Nimbus in 2019.

- $\underline{5}$ Woster, "Clippings and Cuttings" 2008.

- $\underline{6}$ For example, see www.archive.org; https://www.sil.si.edu; and Google images.

- 7 Montgomery, AGG 187.

- 8 Montgomery, AGG 187.

- 9 Montgomery, Red Scrapbook; see also Epperly, Imagining Anne 121. The original scrapbooks are held at the Confederation Centre of the Arts in Charlottetown. Readers wishing to closely examine the scrapbook pages may do so in Imagining Anne, so the original scrapbook pages' equivalent page numbers in Imagining Anne are noted throughout the endnotes.

- 10 Montgomery, Blue Scrapbook; see also Epperly 17.

- 11 Montgomery, Red Scrapbook; see also Epperly 95.

- 12 Montgomery, AGG 202.

- 13 Montgomery, Red Scrapbook; see also Epperly 129.

- 14 Montgomery, AGG 138.

- 15 Montgomery, "Miss Carston's Encore." 
- 16 Russell, Russell, and Wilmshurst, "Lucy Maud Montgomery."

- 17 Montgomery, Blue Scrapbook; see also Epperly 29.

- 18 Hooper, "How Dumas Wrote 'Camille'” 6.

- 19 Montgomery, Blue Scrapbook; see also Epperly 36.

- 20 Montgomery, Als 105.

- 21 Montgomery, AA 139-41.

- 22 Epperly 34.

- 23 Montgomery, Red Scrapbook; see also Epperly 127.

- 24 Church and de Bubna, "The Fringed Gentian" 237.

- 25 Montgomery, "The Alpine Path."

- 26 Shulte, "Observer" 7. Shulte mentions in his column that Carol Gaboury has found the source of "The Fringed Gentian."

- 27 Krout, "Little Brown Hands" 251-2.

- 28 Krout 251-2.

- 29 Montgomery, Red Scrapbook; see also Epperly 146.

- 30 Montgomery, "The Brother" 105.

- 31 Montgomery, "A Case" 105.

- 32 Montgomery, "Winter Dusk" 46.

- 33 Montgomery, "A Country Boy."

- 34 Chadbourne, "The Old School Master's Stories" 385.

- 35 Montgomery, AGG 156.

- 36 Montgomery, Blue Scrapbook; see also Epperly 63.

- 37 Montgomery, Blue Scrapbook; see also Epperly 55.

- 38 Montgomery, Blue Scrapbook; advertisement for Wrisley's 350; see also Epperly 77.

- 39 Dillingham, “The Disposal” 113-14.

\section{Article Info}

Copyright: Carolyn Strom Collins, 2021. This work is licensed under a Creative Commons Attribution 4.0 International License (Creative Commons BY 4.0), which allows the user to share, copy and redistribute the material in any medium or format and adapt, remix, transform and build upon the material for any purpose, even commercially, PROVIDED the Licensor is given attribution in accordance with the terms and conditions of the CC BY 4.0.

Peer reviewed

No 


\section{Works Cited (Introduction)}

Advertisement for Wrisley's Cucumber Complexion Toilet Soap. The Youth's Companion, 2 Aug. 1894, p. 350.

Chadbourne, James D. "The Old School Master's Stories." The Youth's Companion, 6 Sept. 1894, p. 385.

Childs, John Lewis. Catalogues: Fall 1893, 1894, 1895, Spring 1896, 1899, 1900, 1904. [Note: not all of the catalogues give the season of publication.]

Church, Edna Rodman, and Augusta de Bubna. "The Fringed Gentian," in "Tam! The Story of a Woman." Godey's Lady's Book, Mar. 1884, p. 237.

Collins, Carolyn Strom. "L. M. Montgomery's Island Scrapbooks: A Table of Contents with Illustrations." 2020. Unpublished. Available to view at the L.M. Montgomery Institute, Robertson Library, University of Prince Edward Island.

Dillingham, Frances Bent. "The Disposal of Sarah Bell." The Youth's Companion. 8 Mar. 1900, pp. 113-14.

Epperly, Elizabeth Rollins. Imagining Anne: L.M. Montgomery's Island Scrapbooks. Penguin, 2008; Nimbus, 2019. [Note: Same pagination in both editions.]

Hooper, Lucy Hamilton. “How Dumas Wrote 'Camille.'” Ladies' Home Journal, Jan. 1893, p. 6.

Krout, Mary H. "Little Brown Hands." Child Life, edited by John Greenleaf Whittier, Houghton Mifflin, 1881, pp. 251-2.

Montgomery, L.M. “The Alpine Path: The Story of My Career." Everywoman's World, June-Nov. 1917.

---. Anne of Green Gables. L.C. Page, 1908.

---. Anne of Avonlea. L.C. Page, 1909.

---. Anne of the Island. L.C. Page, 1915. 
---. Blue Scrapbook. Circa 1893-1897. Confederation Centre of the Arts, Charlottetown, Prince Edward Island.

---. “The Brother Who Failed," The Globe, Christmas 1909, pp. 18-19.

---. “A Case of Mistaken Identity." American Boy, Feb. 1902, p. 105.

---. “A Country Boy.” Golden Days, 8 Jan. 1898, p. 120.

---. “Miss Carston's Encore.” Shelby County (Missouri) Herald, 13 Jan. 1904.

---. Red Scrapbook. Circa 1890s to mid-1910. Confederation Centre of the Arts, Charlottetown, Prince Edward Island.

---. The Selected Journals of L.M. Montgomery. Edited by Mary Rubio and Elizabeth Waterston, Oxford UP, 1985-2004. 5 vols.

---. “Winter Dusk in the Firs” Zion's Herald, 11 Jan. 1905, p. 46.

Russell, Ruth Weber, D.W. Russell, and Rea Wilmshurst. Lucy Maud Montgomery: A Preliminary Bibliography. U of Waterloo Library, 1986.

Shulte, Bill. "Observer." Kindred Spirits of Vermont (newsletter), Winter 1989, issue 3, p. 7.

Woster, Christy. "Clippings and Cuttings: Sources of Some of the Images and Poetry in L.M. Montgomery's Island Scrapbooks." The Shining Scroll 2008, Periodical of the L.M.Montgomery Literary Society, pp. 15-22.

Immontgomeryliterarysociety.weebly.com/the-shining-scroll-periodical.html.

\section{Works Cited (Video), in order of first appearance or mention}

An asterisk * indicates the item can be found in the Woster-Collins Collection at the Robertson Library at the University of Prince Edward Island.

Blue Scrapbook. Circa 1893-1897. Confederation Centre of the Arts, Charlottetown, Prince Edward Island. 
Red Scrapbook. Circa 1890s to mid-1910. Confederation Centre of the Arts, Charlottetown, Prince Edward Island.

Epperly, Elizabeth R. Imagining Anne: L.M. Montgomery's Island Scrapbooks. Penguin Canada, 2008; Nimbus, 2019.

Woster, Christy. "Clippings and Cuttings: Sources of Some of the Images and Poetry in L.M. Montgomery's Island Scrapbooks." The Shining Scroll 2008, Periodical of the L.M. Montgomery Literary Society, pp. 15-22.

Immontgomeryliterarysociety.weebly.com/the-shining-scroll-periodical.html.

Childs, John Lewis. Catalogues: Circa 1893-1904.

Illustration of pink-and-yellow gladioli. John Lewis Childs Catalogue of Rare Flowers, Vegetables, and Fruits, 1895, p. 4A. (Blue, inside front cover.)

Illustration of purple gladioli. John Lewis Childs Catalogue of Rare Flowers, Vegetables, and Fruits, 1895, p. 4A. (Blue, p. 33.)

Illustration of raspberries and strawberries. John Lewis Childs Catalogue of Rare Flowers, Vegetables, and Fruits, 1895, p. 40A. (Blue, inside front cover.)

Montgomery, L.M. Anne of Green Gables. L.C. Page, 1908.

*Illustration of young woman with lilies. Youth's Companion, Easter 1894. (Blue, p. 2.)

Grey, Lillian. "My Ship.” No publication information found.

Montgomery, L.M. “The Schoolmaster's Bride." Everywoman's World, July 1917, pp. $5,43$.

Montgomery, L.M. Anne's House of Dreams. Stokes, 1917. (See pp. 47-60.)

Montgomery, L.M. "When the Fishing Boats Go Out." The Youth's Companion, Sept. 1899, p. 452.

Illustration of roses and narcissi. John Lewis Childs Fall Catalogue, 1893. (Blue, p. 3.) *Advertisement for Crescent Bicycles. The Youth's Companion, 26 Apr. 1894, p. 200. (Blue, p. 3.) 
*Lennox, May. "In the Portrait Gallery." Ladies' Home Journal, Jan. 1893, p. 4. (Blue, p. 3.)

Montgomery, L.M. “Great-Grandmamma's Portrait.” Maclean's. Nov. 1915, p. 20.

Illustration of girl in white. Ladies' Home Journal, May 1895. (Blue, p. 5.)

*Advertisement for Pears' Soap. Ladies' Home Journal, Sept. 1893, p. 15. (Blue, p. 13.)

*Going, Charles. “Dorothy-A Disappointment." Ladies' Home Journal, Mar. 1894, p. 15. (Blue, p. 13.)

*Waddle, Nancy Mann. "A Study in Leaf Forms." Ladies' Home Journal, May 1895, p. 1. (Blue, p. 13.)

*Howells, William Dean. "The Coast of Bohemia." Ladies' Home Journal, Aug. 1893, p. 7. (Blue, p. 14.)

Montgomery, L.M. "In the Home of Her Mother." Western Christian Advocate, 15 June 1910, pp. 14-16.

Upham, Louise S. "Forget Not the Old Folks at Home." Shelby County Herald, 15 June 1910 (Blue, p. 14.)

Montgomery, L.M. “Miss Carston's Encore." Shelby County (Missouri) Herald, 13 Jan. 1904. (Blue, p. 14.)

Russell, Ruth Weber, D.W. Russell, and Rea Wilmshurst. Lucy Maud Montgomery: A Preliminary Bibliography. U of Waterloo Library, 1986.

*Bridges, Madeline S. "A Touch of Nature." Ladies' Home Journal, May 1895, p. 17. (Blue, p. 14.)

*Illustration of girl in diaphanous gown. Ladies' Home Journal, Apr. 1893. (Blue, p. 18.)

Illustration of rose. John Lewis Childs Catalogue of Rare Flowers, Vegetables, and Fruits, 1895, p. 35. (Blue, p. 18.) 
*Larcom, Lucy. "The First Song-Sparrow." The Youth's Companion. 14 Feb. 1895, p. 80. (Blue, p. 18.)

Cartoon “Bashful." Judge's Library, Sept. 1894, p. 28. (Blue, p. 18.)

Illustration of vase of hyacinths. John Lewis Childs Fall Catalogue, 1893, p. 70. (Blue, p. 19.)

*Hooper, Lucy Hamilton. "How Dumas Wrote 'Camille.'” Ladies' Home Journal, Jan. 1893, p. 6. (Blue, p. 19.)

Montgomery, L.M. Anne of the Island. L.C. Page, 1915.

Montgomery, L.M. Anne of Avonlea. L.C. Page, 1909.

*Advertisement for Lanoline products. Ladies' Home Journal, Dec. 1895, p. 49. (Blue, p. 19.)

Keisel, Conrad. Advertisement for Fry's Cocoa. Illustrated London News, 21 Nov. 1891, p. 688. (Blue, p. 27.)

*Prescott-Davis, N. “Sea Poppies." Illustrated London News, 18 June 1892, p. 761. (Blue, p. 60.)

Illustration of pink-and-blue gloxinia. John Lewis Childs Catalogue of Rare Flowers, Vegetables, and Fruits, spring 1896, p. 8A. (Blue, p. 60.)

*Anonymous. “August." The Youth's Companion, 2 Aug. 1894, p. 349. (Blue, p. 39.)

Illustration of red pansy, purple-and-white pansy. John Lewis Childs Catalogue of Rare Flowers, Vegetables, and Fruits, 1894, p. 3. (Blue, pp. 38, 39.)

Illustration of single gladiolus bloom. John Lewis Childs Catalogue of Rare Flowers, Vegetables, and Fruits, 1894, p. 9. (Blue, p. 42.)

*McCollin, Alice Graham. "The Sunshine of the White House." Ladies' Home Journal, Jan. 1894, p. 7. (Blue, p. 42.)

*Illustration for "The New Year Minuet." Ladies' Home Journal, Jan. 1893. (Blue, p. 44.)

Anonymous. "In the Barn." Cincinnati Enquirer, 15 Feb. 1879. (Blue, p. 44.) 
Montgomery, L.M. “In the Hayloft.” American Agriculturist, 7 July 1906, p. 17.

*Sant, J. "Portrait of a Lady." Illustrated London News, 30 Apr. 1892, p. 10. (Blue, p. 44.)

*Deane, Dorothy. "The Little Brown Dog at the Door." The Youth's Companion, 26 July 1894, p. 338. (Blue, p. 49.)

Montgomery, L.M. Rilla of Ingleside, McClelland and Stewart, 1920. (Blue p. 49.)

Illustration of a small leaf. John Lewis Childs Mayflower Catalogue, 1895, p. 1A. (Blue, p. 49.)

*Advertisement for Henriette Ronner's paintings. Ladies' Home Journal, Jan. 1896, p. 16. (Blue, p. 49.)

*Illustration of single red tulip. John Lewis Childs Mayflower Catalogue, Sept. 1895, p. 257.

Illustration of orange anemone. John Lewis Childs Mayflower Catalogue Fall 1895, Sept. 1895, p. 257. (Blue, pp. 10, 43, 49.)

*Illustration of pink-and-white crocus. John Lewis Childs Mayflower Catalogue, Sept. 1895, p. 257. (Blue, pp. 10, 43, 49.)

Illustration of Japan maples. John Lewis Childs Mayflower Catalogue, 1895, p. 1A. (Blue, pp. 49, 55.)

*Illustration of giant lily. John Lewis Childs Mayflower Catalogue, Dec. 1895. (Blue, p. 58.)

Illustration of blue morning glory. John Lewis Childs Catalogue of Rare Flowers, Vegetables, and Fruits, 1896, p. 4. (Blue, p. 63.)

Illustration of red-and-blue pansy. John Lewis Childs Catalogue of Rare Flowers, Vegetables, and Fruits, 1896, p. 4. (Blue, p. 63.)

*Lanigan. Frances E. "The Woman Who Paints Cats." Ladies' Home Journal, Sept. 1895, p. 3. (Blue, p. 63.)

Ronner, Henriette. Painting of two kittens. In Lanigan. (Blue, p. 63.) 
*Advertisement for Wrisley's Cucumber Complexion Toilet Soap. The Youth's Companion, 2 Aug. 1894, p. 350. (Blue, p. 63.)

Illustration of red roses. John Lewis Childs Catalogue of Rare Flowers, Vegetables, and Fruits, 1896. (Blue, pp. 66, 70.)

Illustration of pink-and-yellow roses in a bouquet. John Lewis Childs Catalogue of Rare Flowers, Vegetables, and Fruits, 1896, p. 2. (Blue, p. 68.)

*Illustration of girl in white. Ladies' Home Journal, Aug. 1895. (Blue, p. 65.)

*Going, Charles B. “The Sleeping of the Wind." Ladies' Home Journal, July 1896, p. 5. (Blue, p. 65.)

Taylor, Bayard. “John Reed's Thoughts." Atlantic Monthly, Mar. 1873, pp. 356-7. Blue, p. 65.)

Illustration of giant moonflower. John Lewis Childs Catalogue of Rare Flowers, Vegetables, and Fruits, 1896, p. 2. (Blue, p. 72.)

*Field, Margaret. "Types and Legends of the Magdalen." Munsey's, June 1895, pp. 256-62. Contains “The Weeping Magdalen” by Murillo, p. 260. (Blue, p. 72.)

*Advertisement for Cosmo Buttermilk Soap. Ladies' Home Journal, May 1896, p. 29. (Blue, inside back cover.)

Photograph of L.M. Montgomery, circa 1900. Montreal Gazette files, undetermined original source. In Montreal Gazette's "Watchword" column by Mark Abley, "Realistic Dialogue Is a Challenge for Novelists." 6 Nov. 2015.

*Illustration of holly wreath. Ladies' Home Journal, Dec. 1902. (Red, inside front cover.)

*Perrine, William. "The Loveliest of All Kentucky Girls." Ladies' Home Journal, Mar. 1901, p. 11. (Red, inside front cover.)

*Illustrations of lady in red, lady in white. Delineator, September 1902, pp. 321, 330. (Red, p. 1.)

*Advertisement for Kodak cameras. Ladies' Home Journal, June 1901. (Red, p. 1.)

*Illustration of lady in red hat. Delineator, September 1902, pp. 321, 330. (Red, p. 1.) 
*"The Grocer's Smile." Advertisement for Quaker Oats. Ladies' Home Journal, Feb. 1903, p. 31. Red, p. 1.)

*Illustration of girl with parasol. Ladies' Home Journal, Sept. 1902. (Red, p. 8.)

*Illustration of woman in a black evening gown. Delineator, Sept. 1902. (Red, p. 9.)

“Fabrics, Trimmings and Accessories." Delineator, Nov. 1902, p. 890.

*“Early Spring Dress Fabrics.” Delineator, Feb. 1903, pp. 392-3.

*Church, Edna Rodman, and Augusta de Bubna. "The Fringed Gentian," in "Tam! The Story of a Woman." Godey's Lady's Book, Mar. 1884, p. 237. (Red, p. 23.)

Montgomery, L.M. "The Alpine Path: The Story of My Career." Everywoman's World, June-Nov. 1917.

Gaboury, Carol. Quoted in Bill Shulte, "Observer," Kindred Spirits of Vermont (newsletter), Winter 1989, issue 3, p. 7.

*Advertisement for B.T. Babbitt's Best Soap. Ladies' Home Journal, May 1901, p. 37. (Red, p. 24.)

*Anonymous. "Madame Ronner and Her Cats." Ladies' Home Journal, Nov. 1899, p. 5. (Red, p. 35.)

*Wilson, Francis. “Lady Jule." Ladies' Home Journal, Nov. 1902, p. 5. (Red, p. 35.)

*Advertisement for Packer's Tar Soap. Ladies' World, Aug. 1910. (Red, p. 35.)

*Illustration of mother and child. Delineator, Feb. 1903. (Red, p. 36.)

Illustration of ruffled pansy. John Lewis Childs Catalogue of Rare Flowers, Vegetables, and Fruits, 1904, p. 4. (Red, p. 36.)

*“For Such as These Is Christmas Day." Ladies' Home Journal, Dec. 1902, pp. 28-9. (Red, p. 36.)

Mitchell, Agnes E. "When the Cows Come Home." Illustrated Christian Weekly, 7 Aug. 1875. (Red, p. 36.) 
Montgomery, L.M. "Going for Cows." [Unverified Ledger title; no publishing information has been found to date.]

Montgomery, L.M. “Milking Time.” Farm Journal, May 1902, p. 161.

*Marcato, Ben. “An Unfortunate Pitch." Ladies' Home Journal, Feb. 1903, p. 19. (Blue, p. 39.)

*Krout, Mary. "Little Brown Hands." Child Life, John Greenleaf Whittier, ed. Houghton Mifflin, 1871, p. 251-2. (Red, p. 39.)

Proctor, Adelaide Anne. "The Lost Chord." 1858. (Red, p. 39.)

*“Mule Barometer.” J.B. Carroll and E.W. Shoneberger, 1906. (Red, p. 42.)

Chadbourne, James D. "An Old School-Master's Stories." The Youth's Companion, 6 Sept. 1894, p. 385.

Dillingham, Frances Bent. "The Disposal of Sarah Bell." The Youth's Companion, 8 Mar. 1900, pp. 113-14. 